\title{
Analysis of Biomass Comminution and Separation Processes in Rotary Equipment - A Review
}

\author{
Petre I. Miu, Post-doc. Research Associate, Ph.D., P.Eng.
}

University of Tennessee, Biosystems Engineering \& Soil Science Department, 2506 E.J. Chapman Drive, Knoxville, TN 37996. pmiu@utk.edu

Alvin R. Womac, Professor, Ph.D., P.E.

University of Tennessee, Biosystems Engineering \& Soil Science Department, 2506 E.J.

Chapman Drive, Knoxville, TN 37996. awomac@utk.edu

Igathinathane Cannayen, Post-doc. Research Associate, Ph.D.

University of Tennessee, Biosystems Engineering \& Soil Science Department, 2506 E.J.

Chapman Drive, Knoxville, TN 37996. igathi@utk.edu

\section{Shahab Sokhansanj, Professor, Ph.D., P.E.}

Oak Ridge National Laboratory, Environmental Sciences Division, Oak Ridge, TN 378316422. sokhansanj@ornl.gov

\author{
Written for presentation at the \\ 2006 ASABE Annual International Meeting \\ Sponsored by ASABE \\ Oregon Convention Center \\ Portland, Oregon \\ 9 - 12 July 2006
}

\begin{abstract}
Biomass utilization for bio-energy, bio-fuels or bio-based products requires reduction of the material size within specific ranges depending on feedstock specie, handling and further processing / conversion processes. Biomass size reduction is a mechanical treatment process that refers to either cutting or comminuting processes that significantly change the particles size, shape and bulk density of organic material.


Rotary equipment such as knife mill, hammer mill and disc mill perform the above-mentioned processes in various ways, as function of physical-mechanical properties of the material, tools geometry, feeding parameters and dynamics of particles separation.

This paper is intended as a comprehensive review of rotary machines design and process investigation that is closely related to material properties as well as requirements for further mechanical or bio-chemical processing.

Keywords. Cutting, Disc mill, Grinding, Hammer mill, Knife mill, Process, Shearing, Size Reduction.

The authors are solely responsible for the content of this technical presentation. The technical presentation does not necessarily reflect the official position of the American Society of Agricultural and Biological Engineers (ASABE), and its printing and distribution does not constitute an endorsement of views which may be expressed. Technical presentations are not subject to the formal peer review process by ASABE editorial committees; therefore, they are not to be presented as refereed publications. Citation of this work should state that it is from an ASABE meeting paper. EXAMPLE: Author's Last Name, Initials. 2006. Title of Presentation. ASABE Paper No. 06xxxx. St. Joseph, Mich.: ASABE. For information about securing permission to reprint or reproduce a technical presentation, please contact ASABE at rutter@asabe.org or 269-429-0300 (2950 Niles Road, St. Joseph, MI 49085-9659 USA). 


\section{Introduction}

Efficient and environmentally sound bio-based power, fuels and other products are expected to represent a major contribution to U.S energy security and economic development (DOE, 2002; Boateng and Hicks, 2005; Dien et al., 2005; McLaughlin and Kszos, 2005; Wyman et al., 2005). Two primary research pathways for developing bio-based products refer to:

- Feedstock supply logistics that includes material handling, size reduction, drying and storage systems for a range of biomass feedstock and condition;

- Fragmentation and separation that isolate high value or target constituents to improve subsequent bioconversion processes of the biomass (DOE, 2002).

Feedstock handling and bioconversion processes require different degrees of biomass size reduction and separation. Following comminution, the improvement of organic materials biochemical treatments can be explained by (Palmovski, 2001; Sun, 2002; Dien et al., 2005):

- Generation of new surface area resulting in a better microorganism accessibility

- Release of dissolved organic components, which are directly bioavailable

- Destruction of material structures which limit the availability for microorganisms / acids.

Size reduction process for certain chemical conversion processes imply grinding the biomass to particle size on the $1 \mathrm{~mm}$ order, which requires one third of the required conversion power (Walsum et al., 1996). The size of waste-materials is usually 10 to $30 \mathrm{~mm}$ after chipping and 0.2 to $2 \mathrm{~mm}$ after milling or grinding (Sun, 2002).

Although milling and grinding represent old methods for feedstock processing, very little is known about comminution processes of biomaterials and interactions within the grinding equipment at a micro-scale. Grinders have generally been analyzed at an overall performance level and treated somewhat as a "black box".

The main objective of this paper is to present a comprehensive review of literature in respect to the following:

- Analysis of physical and mechanical properties of selected biomass materials as influence factors on the comminution processes;

- Inventory and analysis of substantial experimental data obtained from testing of different equipment to reduce the size of biomass;

- Analysis of design of rotary equipment that is suitable for biomass comminution.

Analysis of comminution processes performed by selected rotary equipment with emphasis on material feeding, interactions of material with active elements of equipment, and integration of comminution and separation processes. Moreover, ideas for future research are suggested.

\section{Methods}

This comprehensive review is based on identifying and studying a variety of articles from the ASABE and Science Direct databases, as well as using services of University of Tennessee libraries. In search activity, a multitude of keywords related to biomass properties, materials size reduction processes and corresponding equipment have been used. Information layout takes into account comprehensive results data from the literature then presented in a unified unit system for an easy comparison. 
Data has been organized and structured in an original manner for a better understanding of size reduction related processes as well as an update upon design experience of equipment used for different materials and related comminution processes.

\section{Results}

\section{Biomass Physical and Mechanical Properties}

Physical and mechanical properties of biomass species and varieties are very important when size reduction is performed. A long-term desire in description of biomass size reduction processes would be the modeling of these processes in dependence of inherent material properties.

The first issue in biomass properties research is that physical measurements are extremely difficult in pinpointing exact failure stress and required energy due to differences in terms of material initial size, shape, surface, morphology, etc. this may lead to errors in subsequent modeling of comminution process, which is dynamically performed by a machine such as a knife-mill, hammer-mill, disc-mill etc. (Prince et al., 1968; Womac et al., 2005).

Although 62 species of biomass have been considered (Ebeling and Jenkins, 1985), 35 herbaceous crops were evaluated (Lewandowski et al., 2003). The Integrated Biomass Supply Analysis and Logistics (IBSAL) Model represent an important tool that helps in feedstock selection (Sokhansanj, 2005).

Biomass is mainly composed of non-brittle materials whose behavior can be classified between elastic-plastic and elastic-viscous at a low temperature and high stressing velocity. Depending on moisture content, some brittle particles (fine or small particles) may occur during comminution process. Figure 1 shows a general stress-strain diagram for biomass materials (adapted from Schubert and Bernotat, 2004).

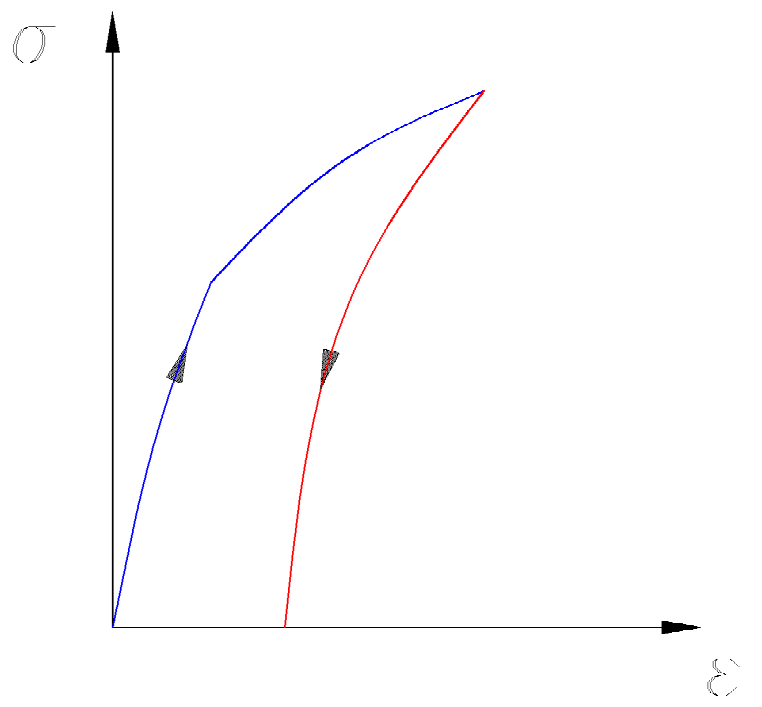

Figure 1. Stress-strain diagram for biomass materials

(Adapted from Schubert and Bernotat, 2004)

It can be noted that stress decreases with constant strain (relaxation) or strain increases under constant stress (creeping), (Schubert and Bernotat, 2004). 
Table 1 presents a synthesis of representative biomass properties as reflected in literature. The analysis of this data led to the following conclusions:

1. Size reduction studies (Yu et al., 2003) at the University of Tennessee of the weakestmode-of-failure of switchgrass indicated that mean shear strength was approximately one-fifth of the tensile strength. That means shear dominant size reduction will be much more efficient (Womac et al., 2005).

2. Up to a 10-fold difference in shear strength was observed between corn stover and hickory wood, with hickory wood requiring larger stresses (Womac et al., 2005).

3. Tensile strength, shear strength and specific cutting energy are significantly influenced by decreasing moisture content of the material due to the changes from a dominant elastic-plastic behavior of the material to a dominant elastic-viscous behavior.

4. Cutterhead bevel angle influences both the failure stress and specific cutting energy, (Sitkei, 1986; Womac et al., 2005).

5. There are significant differences of mechanical properties when measured at the internode or node of the stem (O'Dogherty, 1995; Yore et al., 2002). Therefore, it is necessary to develop methods or models that normalize a certain mechanical property for the whole plant of biomass.

6. Igathi et al. (2005) evaluated 6 isotherm models for describing the moisture sorption characteristics of corn stover components such as corn leaf, stalk skin and pith as functions of equilibrium relative humidity $(\mathrm{ERH})$ and temperature. The moisture content of all components was proportional to $\mathrm{ERH}$ and inversely proportional to temperature.

Development of a comprehensive database of biomass properties will definitely help in designing and optimizing size reduction equipment and associated processes.

\section{Biomass Mechanical Processing Data}

Yu et al. (2003) presented a good review of published studies related to biomass size reduction using knife mills, hammer mills and disc mills. Table 2 presents a unified illustration of the most substantial data that characterizes the biomass mechanical processing with such equipment.

Most of the studies focused on characterizing the overall performance of the tested machines, mainly based on required processing energy versus final size of the material.

Paulrud et al., (2002) evaluated specific surface area of milled wood particles.

Using the ANSI/ASAE S424.1 Standard, Miu and Kutzbach, (2000) proposed a method to quantify the material-other-than-grain (MOG) particle size versus sieve openings size. According to this work, the fragments passing through concave / grates openings (at $84 \%$ cumulative probability) shall be considered to have a geometric mean length of one-half opening's diagonal. Warren et al. (1985) show that, in particulate solids screening, the average particle diameter is $60 \%$ of the opening's diagonal. No other experimental data of biomass particles size separation through sieves has been identified in the literature. This was noted as a limitation in results reported by Li et al., (2004) and Sun and Cheng, (2004).

\section{Biomass Size Reduction Processes withRotary Equipment}

Biomass utilization for bio-energy, bio-fuels or bio-products requires reduction of material size within specific ranges, depending on the feedstock species, handling and further material processing / conversion. 
Size reduction of biomass offers the following advantages (Mani, 2005; Womac 2005; Yu, 2005;):

- Easy handling and drying of bulk material;

- Initial densification (to a certain extent);

- Facile densification through subsequent processing (briquetting, pelleting);

- Reduced costs of transportation;

- Facile sorting of material by size through separation;

- Increased reactive surface area of biomass particles, which are exposed to bio-chemical processing.

Biomass size reduction refers to mechanical treatment processes that significantly change the particle size, shape and bulk density of the material. These processes may involve one or a combination of the following types of actions (Figure 2): cutting, shearing, tearing, impact stress, compression and friction (as in disc milling).
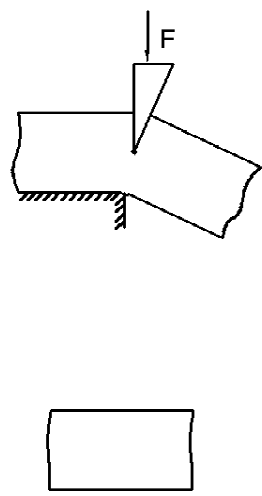

cutting
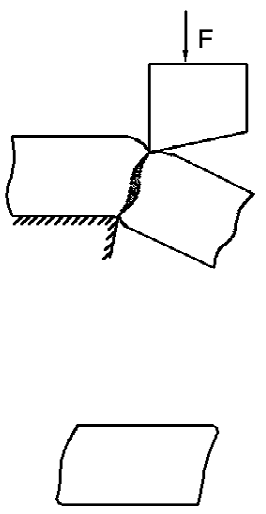

shearing
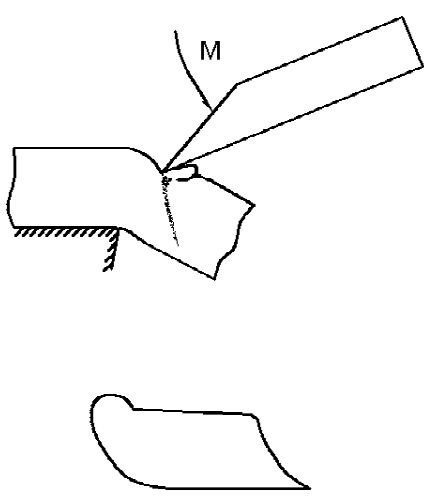

tearing

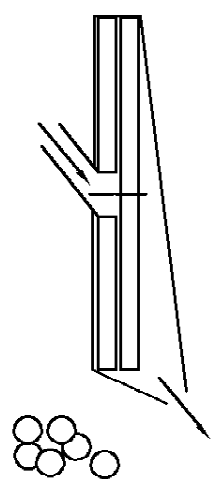

disc milling

Figure 2. Types of actions and corresponding particle shapes

The difference between cutting and shearing is defined by the way of deformation that occurs into the cross-section of material. Sharp knives are used for cutting while working tools with a wedge angle of $75^{\circ}$ to $90^{\circ}$ do the shearing. During cutting process the fracture of material is the result of splitting effect of the knife, while the shearing is the result of shear and tensile stress (Schubert and Bernotat, 2004; Woldt et al., 2004).

During cutting process the deformation of material occurs locally and progressively, close to the tool tip, while during shearing the deformation zone extends before fracture between wedges of cutterhead and stationary knife. As a consequence, the cross-section of cut material is smooth, whereas for a sheared material the cross-section has a specific roughness.

The combination of tensile stress with bending and torsion of the material is called tearing. (Woldt et al., 2004; Schubert and Bernotat, 2004).

Impact loading occurs when a moving tool, such as a hammer, strikes the material. Then the material is usually fired against a fixed rigid target such as perforated surface of a sieve (Austin, 2002). 
Comminution process of biomass can be described as a combination of shearing, torsion, compression and friction of the material with the active elements of equipment. There are three distinguished results of comminution:

a. Particle sizing and classifying (coarse and intermediate size reduction)

b. Particle shaping and

c. Breaking connections between different material components (e.g. cell components).

Therefore, new reactive surfaces for subsequent bio-chemical treatments are created (Palmowski et al., 2001; Müller, 2003; Nikolov, 2004).

Biomass particles have different shapes as a consequence of the stress loadings combination and magnitude applied to a certain material. Mohsenin, (1978) and Sitkei, (1986) presented a general and theoretical study of particle shapes as well as mathematical relationships to quantify an equivalent dimension such as equivalent diameter.

Paulrud et al., (2002) systematically researched wood particle shapes.

Different rotary equipment perform differently the comminution processes as one or more phenomena become dominant in the grinding / milling space. An ideal equipment is the one that, through an innovative combination of stress loadings, it will efficiently disintegrate the material to a certain biomass fineness that corresponds to optimal working / reacting circumstances with microorganisms or chemical substances.

Although rotary equipment is being used, further studies on material fragmentation process (action on stems, deformation, crack propagation etc.) as well as integration with particle separation need to be done. The rationale behind this statement consists in the imperative needs to:

- Understand the comminution and separation processes,

- Quantify the process indices of selected equipment and

- Optimize both the equipment specifications and process parameters.

Not to mention that the results of research done on hard, brittle materials can only be transferred partially to the comminution of biomass materials due to substantial differences in material properties (Palmowski et al., 2001; Müller, 2003).

According to one of paper objectives, in the following section the design of rotary equipment will be analyzed.

\section{Comminution Equipment Classification, Design, and Selection}

In the previous section, we have mentioned different types of stress loadings during size reduction processes. Different equipment design involves applying different combinations of stress loadings. Scubert and Bernotat, (2004) and Woldt et al. (2004) have done a systematic classification of such machines. In the following, the Table 3 and Figure 4 present an extended layout of this classification to better illustrate global experience in material comminution and to suggest further different pathways of biomass processing equipment design and research. Following this classification, we suggest that the knife mill, hammer mill and disc mill are proper equipment for biomass comminution. There are couples of rationales in support of this selection, as follows:

- Knife mills work successfully for shredding forages under various crops and machine conditions (Ige and Finner, 1976; Zhang et al., 2003) 
- Hammer mills are widely used for materials comminution because of their high size reduction ratio, easy adjustment of particles size range as well as a relative good 'cubic' shape of particles (Nikolov, 2004, Mani, 2005). Many researches (Rypma, 1983; Hill and Pulkinen, 1988; Paulrud et al., 2002; Djordjevic et al., 2003; Austin, 2002 and 2004) have used hammer mills in studies of grinding of different materials.

- $\quad$ Disc mills produces very small particles and study of their biomass milling process is therefore very important especially in connection to the size of input material (that might be provided by knife mills or hammer mills) and required specific processing energy.

\section{Cutting, Shearing and Separation Processes in a Knife Mill}

The schematic of a knife mill with a cylinder-type cutterhead is given in the Figure 4a. Based on the literature, the knife mill working process can be characterized as follows (Ige and Finner, 1976; Kepner et al., 1978; Sitkei, 1986; Shinners et al., 2000):

- Particle size depends mainly on feeding velocity and rotational speed of the rotor.

- Required specific cutting energy depends mainly on: material properties, rotational speed of the rotor, mounting longitudinal angle of the knife and bevel angle of the knife.

\section{Comminution and Separation Processes in a Hammer Mill}

In a hammer mill the comminution process is performed through an impact-induced material fragmentation (Austin, 2002 and 2004; Djordjevic, 2003).

In a steady operating state, the throughput of material into the mill can be considered constant. That is mathematically translated to the formula:

$$
\frac{d q}{d t}=0
$$

where:

$$
\begin{aligned}
& q=\text { material throughput },(\mathrm{kg} / \mathrm{s}) \\
& t=\text { time },(\mathrm{s}) .
\end{aligned}
$$

Since there is a time interval between feeding moment and separation moment of considered material, a certain quantity of material is always found in the grinding space that is called 'filling' (Sitkei, 1986). Figure 5 illustrates the graphs of charged and separated quantities of material. Let $t_{1}$ be the moment when the process becomes stable. That means (Sitkei, (1986):

$$
q=\frac{M_{f}}{t_{s}}
$$

where:

$$
\begin{aligned}
& M_{f}=\text { filling amount, }(\mathrm{kg}) \\
& t_{s}=\text { stationary time of material, (s). }
\end{aligned}
$$

We can interpret the time $t_{s}$ as being the time period within the material has one complete revolution. 
Material leaving contact with the hammers reaches the sieve and if small enough it separates through; if it is too big is recirculated to the hold-up (Vogel and Peukert, 2005). There it is mixed with the fed material and the milling process resumes.

At this point we have to emphasize that the time $t_{s}$ is different than the real grinding time $t_{g}$, a small quantity of material spends into the milling space until it separates completely through the screen. During the time $t_{g}$, this quantity of material (small enough to preserve the overall material properties) covers a certain number $n_{r}$ of revolutions inside the milling space $\left(n_{r}>0\right)$. The number of material revolutions depends on design and functional parameters of the hammer mill. It can be quantified by mathematical modeling of the process and confirmed through experimental testing.

\section{Comminution and Separation Processes in a Disc Mill}

Disc mills are fine media mills that are becoming standard particle dispersion equipment in industry (Farber and Graves, 2001). They are built in a single or double disc version with both straight and profiled blades. Material is fed into the mill through a central orifice coaxial with rotation axis, and then following acceleration by means of rotating blades, material is fragmented between the discs and flows to their periphery. The discs can have straight or profiled blades. Other disc mills perform the final fragmentation of material between the rotating disc and a ring-like stator coaxial with the rotor (Eskin \& Kalman, 2000). Extensive testing has confirmed that shear and compression are predominant comminution mechanisms in these types of mills.

In studying the process of disc mills the following assumptions are taken into consideration (Eskin and Kalman, 2000; Farber and Graves, 2001):

- Material is uniformly distributed with a low numerical concentration of particles; therefore particle interaction is neglected;

- The effect of gravity is neglected;

- Material flows parallel to the rotating disc surface, without rolling, that intensifies the shearing process of particles.

The percentage of required energy for particle acceleration is approximately the same for all types of the blades (Eskin and Kalman, 2002).

\section{Conclusions}

This paper analyses the state-of-art of biomass size reduction using rotary equipment, as presented in literature. The following biomass species have been mostly investigated: switchgrass, cornstover, hickory wood, wheat, barley and rice straw.

A long-term desire in quantifying of biomass comminution processes would be:

- Development of a comprehensive database of biomass properties (summary presented in Table 1)

- Imbedding biomass properties in mathematical models of size reduction processes performed by different equipment.

Previous researches on hammer mill and knife mill reported some experimental results of mechanical processing of biomass (Table 2) in terms of required specific processing energy. Much more efforts and resources need to be spent in this direction. 
Analysis of type of actions (loadings), Figure 2), of active organs of rotary equipment lead to the conclusion that further studies on material fragmentation processes as well as integration with particle separation need to be done.

Following the classification and design analysis of existing rotary equipment (Table 3 and Figure 4 ), the paper presents the reasons in support of knife mill, hammer mill and disc mill selection as the most appropriate equipment for biomass processing. Optimization of comminution processes of such equipment as well as development of new equipment represent logical research steps to be taken in the future.

\section{References}

Annoussamy, M., G. Richard, S. Recous and J. Guerif. 2000. Change in mechanical properties of wheat straw due to decomposition and moisture. Applied Eng. In Agric. 16(6):657664.

ANSI / ASAE Standard, 2001. S424.1: Method of Determining and Expressing Particle Size of Chopped Forage Materials by Screening. St. Joseph, Mich.: ASAE.

ASAE Standards, 2003b. S472: Terminology for Forage Harvesters and Forage Harvesting. St. Joseph, Mich.: ASAE.

Austin, L.G. 2002. A treatment of impact breakage of particles. Powder Technology, (126): 8590.

Austin, L. G. 2004. A preliminary simulation model for fine grinding in high speed hammer mills. Powder Technology, 143-144: 240-252.

Boateng, A.A. and K.B. Hicks. 2005. Pyrolysis of switchgrass (Panicum virgatum) harvested at several stages of maturity. J. Analytical and Applied Pyrolysis. Xxx (2005) xxx-xxx. Accessed at www.sciencedirect.com Dec. 2005.

DOE. 2002. Roadmap for Biomass Technologies in the United States. Office of the Biomass Program, U.S. Department of Energy. http://www.bioproducts-bioenergy.gov./pdfs/Final BiomassRoadmap.pdf. Accesses Oct. 2005.

Dien, B.S., L.B. Iten and C.D. Skory. 2005. Converting herbaceous energy crops to bioethanol: A review with emphasis on pretreatment process. In Handbook of Industrial Catalysis, 111. Boca Raton, FL.

Djordjevic, N., F. N. Shi and R. D. Morrison. 2003. Applying discrete element modeling to vertical and horizontal shaft impact crushers. Minerals Engineering 16: 983-991.

Ebeling, J.M. and B.M. Jenkins. 1985. Physical and chemical properties of biomass fuels. Transactions of the ASAE 28(3): 898-902.

Eskin, D and H. Kalman. 2000. Optimal particle acceleration in a centrifugal rotor-impact mill. Minerals Engineering, 13(14-15): 1653-1658.

Eskin, D. and H. kalman. 2002. Problems of optimal particle acceleration on straight linear blades of centrifugal rotor-impact mills. Powder Technology 123 (1): 75-82

Farber, B. Ya and G. A. Graves. 2001. Horizontal mill friendly ceramic media with improved efficiency. http://www.zircoa.com/product.fine.grain/mill.mates.reprint.html. Accessed on Jan. 2006.

Hamman, K.D., R.L. Williamson, E.D. Steffler, C.T. Wright, J.R. Hess and P.A. Pryfogle. 2005. Structural analysis of wheat stems. Applied Biochem. And Biotechnology (121-124): 7180. 
Hill, B. and D.A. Pulkinen. 1988. A study of the factors affecting pellet durability and pelleting efficiency in the production of dehydrated alfalfa pellets. A special report. Saskatchewan Dehydrators Association, Tisdale, SK, Canada

Husemann Klaus. 2004. Zur Modellierung von Zerkleinerungsprozessen. Partikeltechnologie Symposium. Paper No. 2004-07086. Pfinztal.

Ige, M. T. and M. F. Finner. 1976. Optimization of the performance of the cylinder type forage harvester cutterhead. Transactions of the ASAE, 19(3): 455-460.

Jannasch, R., Y. Quan and R. Samson. A process and energy analysis of palletizing switchgrass. Resource Efficient Agricultural Production (REAP-Canada). www.reapcanada.com. Accessed on Nov. 2005.

Jäckel, H.G. and G. Schubert. 1997. Chemieingenieurtechnik. 69(5): 640-647.

Lakes, R. 2001. Negative Poisson's Ratio Materials. http://silver.neep.wisc.edu/ lakes/ (accessed Dec. 2005)

Li, Y., R. Ruan, P.L Chen, Z. Liu, X. Pan, Y. Liu, C.K. Mok and T. Yang. 2004. Enzymatic hydrolysis of corn stover pretreated by combined dilute alkaline treatment and homogenization. Transactions of the ASAE. 47(3): 821-825.

Kepner, R. A., R. Bayner and E. L. Barger. 1978. Principles of Farm Machinery, AVI Publishing Company, Inc., Westport, Connecticut.

Kronbergs, E. 2000. Mechanical strength testing of stalk materials and compacting energy evaluation. Industrial Crops and Products. (11): 211-216.

Mani, S., L.G. Tabil and S. Sokhansanj. 2002. Grinding performance and physical properties of selected biomass. ASAE Paper No. 02-6175. St. Joseph, Mich.: ASAE.

Mani, S., L.G. Tabil, S. Sokhansanj and M. Roberge. 2003. Mechanical properties of corn stover grind. ASAE Paper No. 03-6090. St. Joseph, Mich.: ASAE.

McLaughlin, S.B and L.A. Kszos. 2005. Development of switchgrass (Panicum virgatum) as a bioenergy feedstock in the United States. Biomass and Bioenergy 28: 515-535.

Miu, P.I. and H.-D. Kutzbach. 2000. Simulation of threshing and separation processes in threshing units. Agrartechnische Forschung 6(S): 1-7

Mohsenin, N. 1986. Physical Properties of Plant and Animal Materials. Gordon and Breach, Science Publishers, Inc. New York, Second revised and updated Revision.

Müller, J.A. 2003. Comminution of Organic Material. Chemie Engineering Technology. 26(2): 207-217.

Nikolov, S. 2004. Modeling and simulation of particle breakage in impact crushers. Int. Journal of Mineral Processing. 74(S): 219-225.

O'Dogherty, M. J., J. A. Hubert, J. Dyson and C.J. Marshall. 1995. A study of the physical and mechanical properties of wheat straw. J. Agric. Engng. Res. 62: 133-142.

Oran, E.S. 2002. AIAA Journal (40):1481-1494

Palmowski, L., J. Müller and J. Schwedes. 2001. Comminution of organic materials to improve their bioavailabilty. Eng. Life Sci. 1(3): 121-125.

Paulrud, S., J. E. Mattson and C. Nilsson. 2002. Particle and handling characteristics of wood fuel powder: effects of different mills. Fuel Processing Technology. 76(2002):23-39.

Prince, R.P., D. D. Wolf and J.W. Bartok, Jr. 1968. Mechanical Properties of corn stalks. Research Report 29. University of Connecticut, Storrs, Connecticut.

Reith, J.H., H. den Uil, H. van Veen, W.T.A.M de Laat, J.J. Niessen, E. de Jong, H.W. Elbersen, R. Weusthuis, J.P. van Dijken and L. Raamsdonk. 2002. Co-production of bio-ethanol, electricity and heat from biomass residues. $12^{\text {th }}$ European Conference and Technology 
Exhibition for Energy, Industry and Climate Protection. Paper No. ECN-RX-02-030. Amsterdam, the Nederlands.

Roberge, M. P. Savoie and E. R. Norris. 1998. Evaluation of a crop processor in a pull-type forage harvester. Transactions of the ASAE 41(4): 967-972.

Rypma, J. A. 1983. What the European feed manufacturer requires in particle reduction equipment and systems. Proceedings of First International Symposium on Particle Size Reduction in the Feed Industry, B-11. Manhattan, KS.

Sander, S., G. Schubert and H.-G. Jäckel. 2004. The fundamentals of the comminution of metals in shredders of the swing-hammer type. International Journal of Mineral Processing. 74S(2004): 385-393.

Schubert, G and S. Bernotat. 2004. Comminution of non-brittle materials. International Journal of Mineral Processing. 74S(2004): 19-30.

Shinners, K. J., A. G. Jirovec, R. D. Shaver and M. Bal. 2000. Prpcessing wilted alfalfa with crop processing rolls on a pull type forage harvester. Applied Eng. in Agriculture, 16(4): 333340.

Sitkei, György1986. Mechanics of Agricultural Materials. Amsterdam, Oxford, New York. Elsevier

Sokhansanj, S. 2001. Integrated Biomass Supply Analysis and Logistics (IBSAL). Oak Ridge National Laboratory, Oak Ridge, Tennessee.

Sun, Y. 2002. Enzymatic hydrolysis of rye straw and bermudagrass for ethanol production. PhD diss. Raleigh, N.C.: North Carolina State University, Department of Biological and Agricultural Engineering.

Sun, Y. and J. Cheng. 2004. Enzymatic hydrolysis of rye straw and bermudagrass using cellullases supplemented with $\beta$-glucosidase. Transactions of the ASAE. 47(1): 343-349.

Tribelhorn, R. E. and J. L. Smith. 1975. Chopping energy of a forage harvester. Transactions of the ASAE. 18(3): 423-426.

Vogel, L. and W. Peukert. 2004. Determination of material properties relevant to grinding by practicable labscale milling tests. Int. Journal of Mineral Processing, 74(S): 329-338.

Vogel, L. and W. Peukert. 2005. From single particle behaviour to modeling of impact mills. Chemical Engineering Science 60: 5164-5176.

Warren, L.McC., J.C. Smith and P. Harriott. 1985. Unit Operations of Chemical Engineering. McGraw-Hill, Inc., New York.

Woldt, D., G. Schubert and H.-G. Jäckel. 2003. Zerkleinerung nicht-spröder Stoffe in Rotorscheden. GVC Fachausschusssitzung Zerkleinern/Klassieren. Paper No. 200303258.

Woldt, D. ., G. Schubert and H.-G. Jäckel. 2004. Size-reduction by means of low-speed rotary shears. International Journal of Mineral Processing. 74S (2004): 405-415.

Womac, A.R., M. Yu, C. Igathinathane, P. Ye, D. Hayes, S. Narayan, S. Sokhansanj and L. Wright. 2005. Shearing characteristics of biomass for size-reduction. ASAE Paper No. 056058. St. Joseph, Mich.: ASAE. 


\section{Appendix or Nomenclature}

Table 1. Representative biomass physical and mechanical properties.

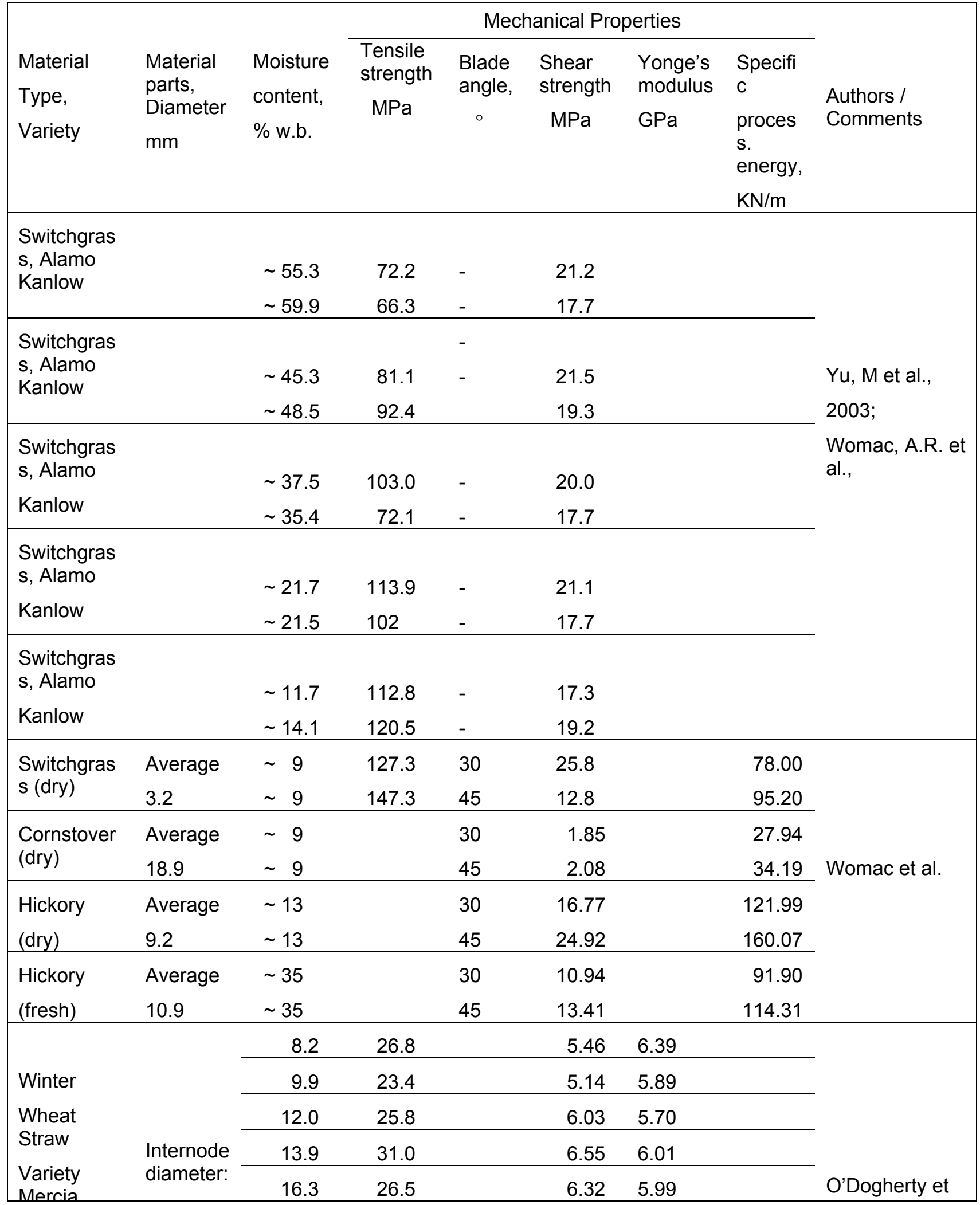




\begin{tabular}{|c|c|c|c|c|c|c|c|}
\hline \multirow{3}{*}{$\begin{array}{l}\text { Mercia, } \\
\text { (Fourth } \\
\text { stage of } \\
\text { maturity }\end{array}$} & \multirow{3}{*}{$\begin{array}{l}3.70- \\
3.80\end{array}$} & 17.7 & 24.3 & 6.39 & 6.23 & & \multirow{3}{*}{$\begin{array}{l}\text { al. } \\
1995\end{array}$} \\
\hline & & 20.1 & 31.2 & 6.47 & 5.73 & & \\
\hline & & 22.0 & 22.7 & 6.51 & 5.89 & & \\
\hline \multirow{4}{*}{$\begin{array}{l}\text { Winter } \\
\text { Wheat } \\
\text { Straw } \\
\text { Var. Mercia } \\
\text { (Fourth } \\
\text { stage of } \\
\text { maturity) }\end{array}$} & $\begin{array}{l}2.56- \\
2.71\end{array}$ & 9.3 & 23.8 & 5.74 & 5.21 & & \multirow{4}{*}{$\begin{array}{l}\text { O'Dogherty et } \\
\text { al. } 1995\end{array}$} \\
\hline & $\begin{array}{l}3.32- \\
3.51 \\
\end{array}$ & 8.3 & 28.4 & 6.29 & 6.59 & & \\
\hline & $\begin{array}{l}3.70- \\
3.80\end{array}$ & 7.8 & 28.2 & 5.58 & 6.04 & & \\
\hline & $\begin{array}{l}3.94- \\
4.06\end{array}$ & 7.5 & 21.2 & 4.91 & 6.14 & & \\
\hline \multirow{4}{*}{$\begin{array}{l}\text { Wheat } \\
\text { internodes } \\
\text { (dry) }\end{array}$} & $2.6 \mathrm{~mm}$ & & 26.9 & 5.10 & 3.70 & 12.90 & \multirow{4}{*}{$\begin{array}{l}\text { Annoussamy et } \\
\text { al., } \\
2000\end{array}$} \\
\hline & $3.8 \mathrm{~mm}$ & & 17.9 & 4.60 & 3.00 & 20.76 & \\
\hline & $3.9 \mathrm{~mm}$ & & 15.0 & 4.40 & 2.60 & 15.70 & \\
\hline & $3.5 \mathrm{~mm}$ & & 3.5 & 4.40 & 3.20 & 15.65 & \\
\hline Wheat & & 10 & 118.7 & 8.47 & 13.1 & & $\begin{array}{l}\text { Kronbergs, } \\
2000\end{array}$ \\
\hline \multirow{3}{*}{$\begin{array}{l}\text { Wheat } \\
\text { straw }\end{array}$} & & & & & $4.8-6.6$ & & Oran, 2002 \\
\hline & & & & & $4.1-$ & & Lakes, 2004 \\
\hline & & & & & $0.99-1.3$ & & Hamman, 2005 \\
\hline Corn stover & & & & & $0.26-$ & & Wright, 2005 \\
\hline Rice & & & & 8.36 & & 4.17 & Palmowski \\
\hline
\end{tabular}

Table 2. Biomass mechanical processing data - a review.

\begin{tabular}{|c|c|c|c|c|c|c|c|}
\hline $\begin{array}{l}\text { Material } \\
\text { Type } \\
\text { Variety }\end{array}$ & $\begin{array}{l}\text { Initial / Final } \\
\text { size } \\
\mathrm{mm}\end{array}$ & $\begin{array}{l}\text { Moisture } \\
\text { content, } \\
\% \text { w.b. }\end{array}$ & $\begin{array}{l}\text { Equipment / } \\
\text { Process }\end{array}$ & $\begin{array}{l}\text { Equipment } \\
\text { Specifications }\end{array}$ & $\begin{array}{l}\text { Bulk / } \\
\text { Particle } \\
\text { Density, } \\
\mathrm{kg} / \mathrm{m}^{3} \\
\end{array}$ & $\begin{array}{l}\text { Required } \\
\text { Processing } \\
\text { Energy } \\
\text { kwh/t }\end{array}$ & $\begin{array}{l}\text { Authors / } \\
\text { Comments }\end{array}$ \\
\hline \multirow[t]{3}{*}{ Switchgrass } & \multirow{3}{*}{$\begin{array}{l}\text { Bale / 2.5- } \\
10 \mathrm{~cm} \\
2.5-10 \mathrm{~cm} /\end{array}$} & \multirow{3}{*}{$\begin{array}{l}7.5- \\
10.3\end{array}$} & - Chopping & $\mathrm{N} / \mathrm{A}$ & & 14.9 & \multirow[t]{3}{*}{ Jonasch, } \\
\hline & & & - Fine grndg. & $2.78 \mathrm{~mm}$ sieve & & 55.9 & \\
\hline & & & - Pelleting & opening & & 74.5 & \\
\hline Switchgrass & & & Hammermill & $5.6 \mathrm{~mm}$ opng. & & 44.9 & $\begin{array}{l}\text { Samson, } \\
2000\end{array}$ \\
\hline \multirow{4}{*}{ Switchgrass } & / 0.794 & \multirow{3}{*}{8} & \multirow{4}{*}{ Hammermill } & & & 62.62 & \multirow{4}{*}{$\begin{array}{l}\text { Mani et al. } \\
2002\end{array}$} \\
\hline & / 1.588 & & & & & 51.83 & \\
\hline & / 3.175 & & & & & 23.50 & \\
\hline & / 0.794 & & & & & 55.63 & \\
\hline
\end{tabular}




\begin{tabular}{|c|c|c|c|c|c|c|}
\hline \multirow{4}{*}{\begin{tabular}{|l} 
\\
Cornstover
\end{tabular}} & / 1.588 & \multirow[t]{2}{*}{12} & & \multirow{2}{*}{\multicolumn{3}{|c|}{$\begin{array}{l}58.57 \\
27.17 \\
\end{array}$}} \\
\hline & \multicolumn{2}{|l|}{ / 3.175} & & & & \\
\hline & / 0.682 & \multirow[t]{2}{*}{7} & \multirow[t]{2}{*}{ Hammill } & $\begin{array}{l}6.35 \mathrm{~mm} \text { sieve } \\
\text { opening }\end{array}$ & $\begin{array}{l}111.73 \\
/ 1085\end{array}$ & \multirow{2}{*}{$\begin{array}{l}\text { Mani et al } \\
2003\end{array}$} \\
\hline & / 0.407 & & & $\begin{array}{l}3.18 \mathrm{~mm} \text { sieve } \\
\text { opening }\end{array}$ & $\begin{array}{r}130.30 \\
/ \quad 1210 \\
\end{array}$ & \\
\hline \multirow{6}{*}{ Cornstover } & 7.15 / 0.794 & \multirow{3}{*}{6.2} & \multirow{6}{*}{ Hammermill } & & \multirow{2}{*}{$\begin{array}{l}22.07 \\
14.79\end{array}$} & \multirow{6}{*}{$\begin{array}{l}\text { Mani et al. } \\
2002\end{array}$} \\
\hline & $7.15 / 1.588$ & & & & & \\
\hline & $7.15 / 3.175$ & & & & 6.96 & \\
\hline & 7.15 / 0.794 & \multirow{3}{*}{12} & & & 34.30 & \\
\hline & $7.15 / 1.588$ & & & & 19.84 & \\
\hline & $7.15 / 3.175$ & & & & 11.04 & \\
\hline \multirow{5}{*}{ Cornstover } & $/ 1.60$ & & \multirow[t]{2}{*}{ Hammermill } & & 14.00 & \multirow{3}{*}{$\begin{array}{l}\text { Cadoche } \\
\text { and }\end{array}$} \\
\hline & / 3.20 & & & & 9.60 & \\
\hline & / 3.20 & & \multirow{3}{*}{ Knife mill } & & 20.00 & \\
\hline & / 6.35 & & & & 15.00 & \multirow{2}{*}{$\begin{array}{l}\text { Lopez, } \\
1989\end{array}$} \\
\hline & 19.50 & & & & 3.20 & \\
\hline \multirow{6}{*}{ Wheat straw } & 7.67 / 0.794 & \multirow{3}{*}{8.3} & \multirow{6}{*}{ Hammermill } & & 51.55 & \multirow{6}{*}{$\begin{array}{l}\text { Mani et al. } \\
2002\end{array}$} \\
\hline & 7.67 / 1.588 & & & & 39.59 & \\
\hline & $7.67 / 3.175$ & & & & 10.77 & \\
\hline & 7.67 / 0.794 & \multirow{3}{*}{12} & & & 45.32 & \\
\hline & $7.67 / 1.588$ & & & & 43.56 & \\
\hline & $7.67 / 3.175$ & & & & 24.66 & \\
\hline \multirow[t]{5}{*}{ Barley straw } & $20.52 / 0.794$ & 6.9 & Hammermill & & 53.00 & $\begin{array}{l}\text { Mani et al. } \\
2002\end{array}$ \\
\hline & $20.52 / 1.588$ & & & & 27.09 & \\
\hline & $20.52 / 3.175$ & & & & 13.56 & \\
\hline & $20.52 / 0.794$ & 12 & & & 99.49 & \\
\hline & $20.52 / 1.588$ & & & & 42.82 & \\
\hline
\end{tabular}


Table 3. Classification of biomass comminution equipment

\begin{tabular}{|c|c|c|c|c|c|}
\hline $\begin{array}{l}\text { Equipment } \\
\text { Type }\end{array}$ & Description & Speed & Clearance & Specifications & $\begin{array}{l}\text { Schematic } \\
\text { representation }\end{array}$ \\
\hline \multirow{2}{*}{ Rotary cutters } & $\begin{array}{l}\text { Cylinder } \\
\text { cutterhead }\end{array}$ & $20 \mathrm{~m} / \mathrm{s}$ & $\begin{array}{l}\text { Radial } \\
\text { gap }\end{array}$ & $\begin{array}{l}4-8 \text { cutterhead knives } \\
\text { Knife rake angle } \\
\text { Knife helix angle } \\
1 \text { stationary knife }\end{array}$ & Figure 4-a \\
\hline & Wiley mill & & $\begin{array}{l}\text { Radial } \\
\text { gap }\end{array}$ & $\begin{array}{l}4-6 \text { cutterhead knives } \\
4 \text { stationary knives or } \\
\text { counterhead knives }\end{array}$ & Figure 4-b \\
\hline \multirow{4}{*}{ Rotary shears } & One-rotor shear & & \multirow[t]{2}{*}{ Axial gap } & & Figure 4-c \\
\hline & Two-rotor shear & & & & Figure 4-d \\
\hline & $\begin{array}{l}\text { Indexable knife } \\
\text { shear }\end{array}$ & & $\begin{array}{l}\text { Radial } \\
\text { gap }\end{array}$ & & Figure 4-e \\
\hline & Block knife shear & & & & \\
\hline \multirow{4}{*}{$\begin{array}{l}\text { Rotary } \\
\text { shredders }\end{array}$} & Swing-hammer mill & & $\begin{array}{l}\text { Radial } \\
\text { gap }\end{array}$ & $4-8$ rows w/knives & Figure 4-f \\
\hline & Shredders w/ pins & & & & \\
\hline & $\begin{array}{l}\text { Shredders w/ } \\
\text { knives }\end{array}$ & & Axial gap & & \\
\hline & $\begin{array}{l}\text { Shredders w/ } \\
\text { toothed slats }\end{array}$ & & & & \\
\hline
\end{tabular}




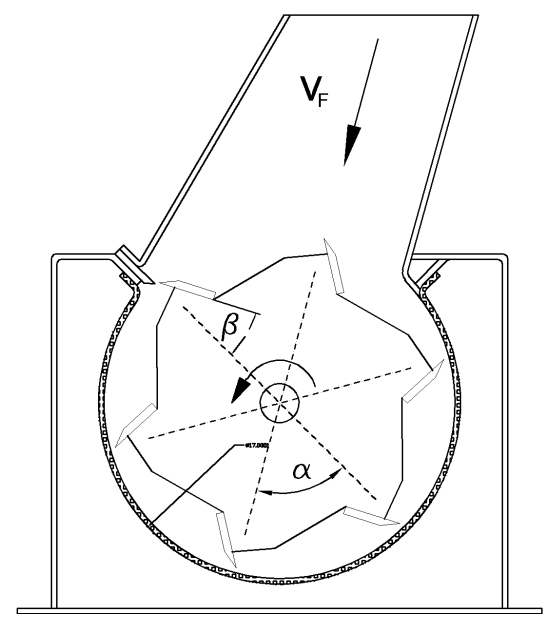

a

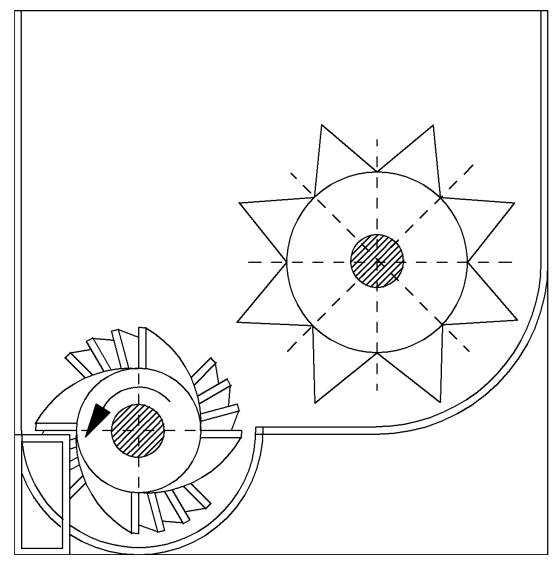

C

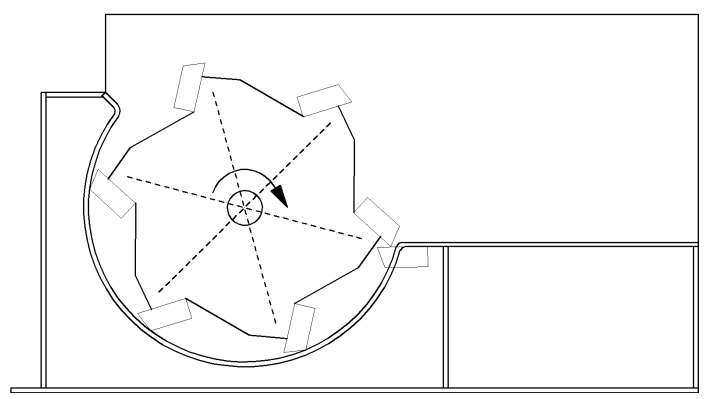

e

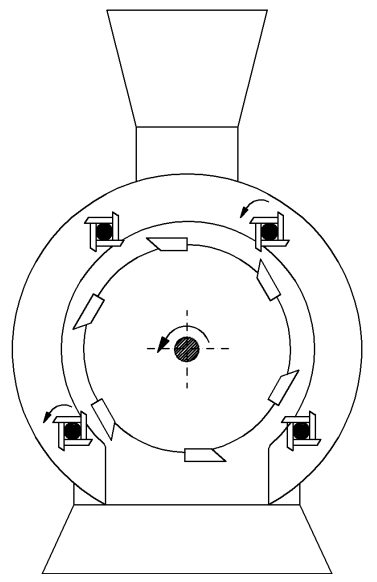

b

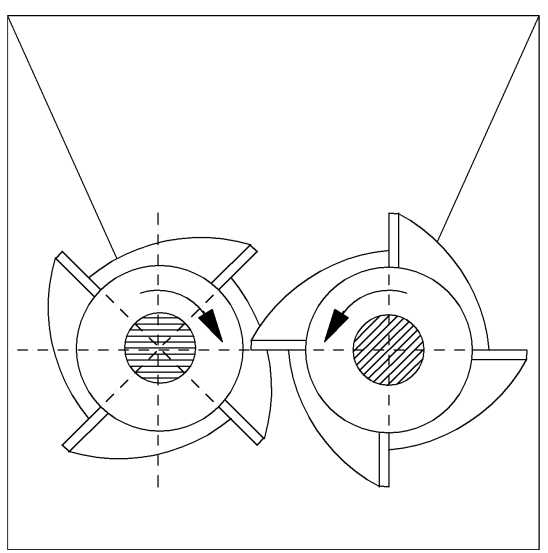

d

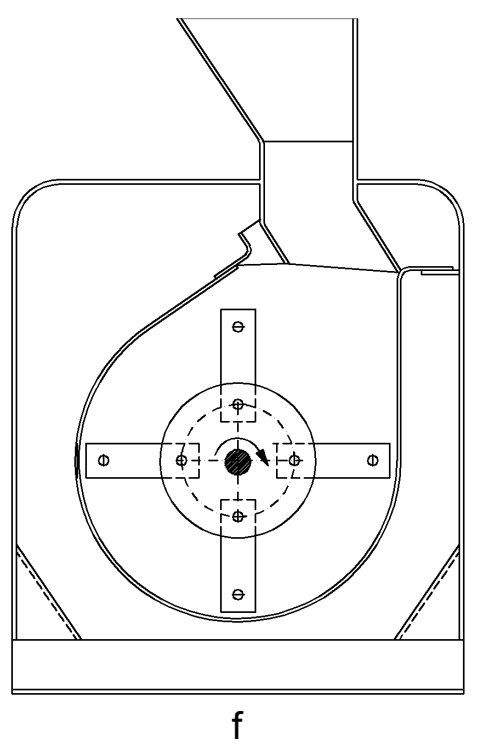

Figure 4. Design of rotary equipment for biomass size-reduction 


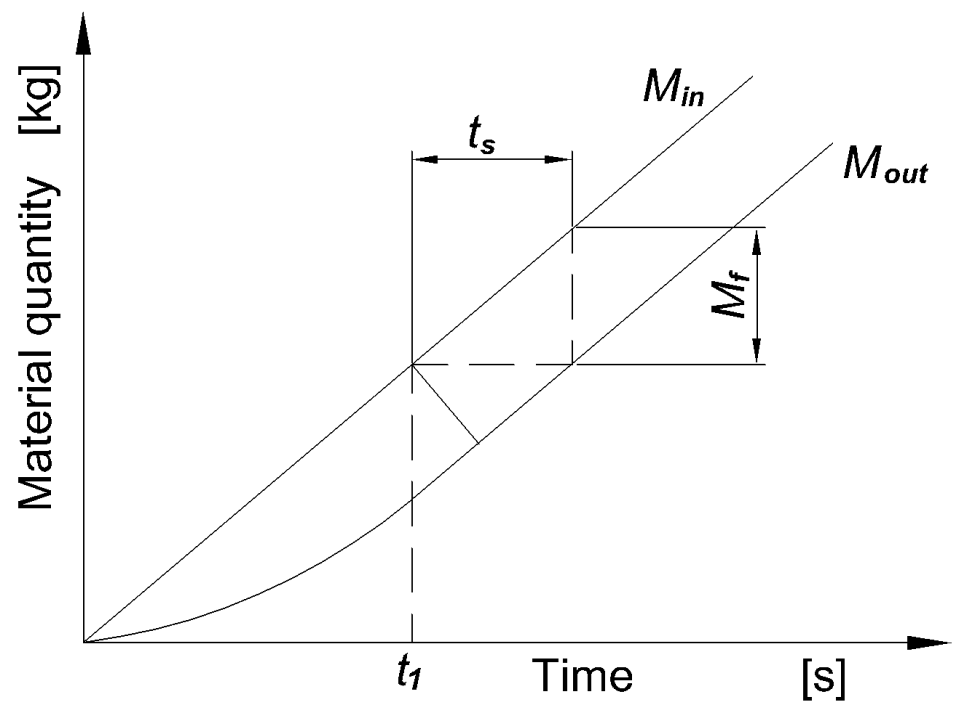

Figure 5. Operation diagram of a hammer mill 